Article

\title{
Amycolachromones A-F, Isolated from a Streptomycin-Resistant Strain of the Deep-Sea Marine Actinomycete Amycolatopsis sp. WP1
}

\author{
Jianwei Chen ${ }^{1,+}$, Jun Chen ${ }^{2,+}$, Siqi Wang ${ }^{1}$, Xiaoze Bao ${ }^{1}$, Songwei Li ${ }^{1}$, Bin Wei ${ }^{1}$, Huawei Zhang ${ }^{1}$ D \\ and Hong Wang $1,3, *(\mathbb{D}$
}

Citation: Chen, J.; Chen, J.; Wang, S.; Bao, X.; Li, S.; Wei, B.; Zhang, H.;

Wang, H. Amycolachromones A-F, Isolated from a StreptomycinResistant Strain of the Deep-Sea Marine Actinomycete Amycolatopsis sp. WP1. Mar. Drugs 2022, 20, 162. https://doi.org/10.3390/ md20030162

Academic Editors: Orazio Taglialatela-Scafati and Ipek Kurtboke

Received: 25 January 2022

Accepted: 22 February 2022

Published: 24 February 2022

Publisher's Note: MDPI stays neutral with regard to jurisdictional claims in published maps and institutional affiliations.

Copyright: (c) 2022 by the authors. Licensee MDPI, Basel, Switzerland. This article is an open access article distributed under the terms and conditions of the Creative Commons Attribution (CC BY) license (https:// creativecommons.org/licenses/by/ $4.0 /)$.
1 College of Pharmaceutical Science \& Collaborative Innovation Center of Yangtze River Delta Region Green Pharmaceuticals, Zhejiang University of Technology, Hangzhou 310014, China; cjw983617@zjut.edu.cn (J.C.); 2112007272@zjut.edu.cn (S.W.); baoxiaoze@zjut.edu.cn (X.B.); songweili93@zjut.edu.cn (S.L.); binwei@zjut.edu.cn (B.W.); hwzhang@zjut.edu.cn (H.Z.)

2 College of Biotechnology and Pharmaceutical Engineering, West Anhui University, Lu'an 237499, China; 02000179@wxc.edu.cn

3 Key Laboratory of Marine Fishery Resources Exploitment and Utilization of Zhejiang Province, Zhejiang University of Technology, Hangzhou 310014, China

* Correspondence: hongw@zjut.edu.cn; Tel.: +86-0571-8832-0622

+ These authors contributed equally to this work.

\begin{abstract}
In this study, a detailed chemical investigation of a streptomycin-resistant strain of the deep-sea marine, actinomycete Amycolatopsis sp. WP1, yielded six novel amycolachromones A-F (1-6), together with five known analogues (7-11). Amycolachromones A-B (1-2) possessed unique dimer skeletons. The structures and relative configurations of compounds 1-11 were elucidated by extensive spectroscopic data analyses combined with $\mathrm{X}$-ray crystal diffraction analysis. Plausible biogenetic pathways of amycolachromones A-F were also proposed.
\end{abstract}

Keywords: marine actinomycetes; secondary metabolites; isolation

\section{Introduction}

Marine microbial natural products, especially those derived from marine actinomycetes, have become an important source of novel bioactive compounds [1-3]. However, traditional screening strategies generally do not provide access to the full array of secondary metabolites encoded within actinomycete genomes [4]. For example, Streptomyces coelicolor initially produces four classes of metabolites using laboratory fermentation, despite genome sequencing revealing the capacity to produce $>30$ families of metabolites $[5,6]$. To solve this problem, various strategies have been proposed to activate the expression of otherwise silent biosynthetic gene clusters, including the 'one strain many compounds' (OSMAC) approach [7], co-cultivation with other microorganisms [8] and chemical epigenetics [9]. Recently, a ribosome engineering approach that targets ribosomal proteins or RNA polymerase (RNAP) has shown promise for expression of cryptic gene clusters. This method selects for mutants that are resistant to antibiotics that target the bacterial ribosome, presumably activating the expression of bacterial cryptic genes by resistant mutants $[10,11]$. Shima and co-workers demonstrated this method in actinomycetes by activating the biosynthetic pathway for actinorhodin in mutant Streptomyces that developed resistance to streptomycin [12]. Recent adoptions of this approach demonstrated the ability of streptomycin-resistant mutants to enhance production of actinolactomycin [13], fredericamycin A and chlorinated alkaloids, inducamides A-C [14,15].

Chromones are oxygen-containing heterocyclic compounds with a chromone benzoannelated $\gamma$-pyrone ring (4H-chromen-4-one, $4 \mathrm{H}$-1-benzopyran-4-one) that are widely distributed in bacteria, fungi and plant [16]. Chromones and analogues can be considered 
privileged structures in drug discovery due to their numerous biological activities, such as anti-inflammatory, antiplatelet, anticancer, antimicrobial, anti-neurodegenerative and anti-obesity effects [17]. In this paper, we undertook a ribosome engineering approach for activating biosynthetic pathways in Amycolatopsis sp. WP1, a deep sea actinomycete isolated from sediments collected at $-2945 \mathrm{~m}$ in the Indian Ocean. A streptomycin-resistant strain, designated as L-30-6 (Figure 1), was observed to produce six new chromone derivatives, designated as the amycolachromones A-F (1-6), and five known chromone derivatives (7-11) (Figure 2).

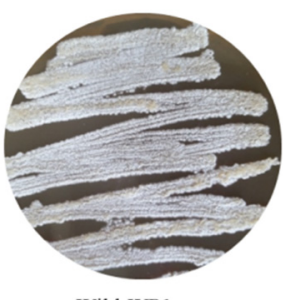

Wild-WP1

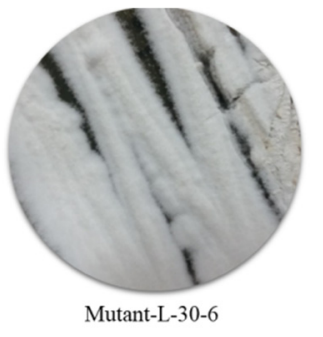

UV at $300 \mathrm{~nm}$

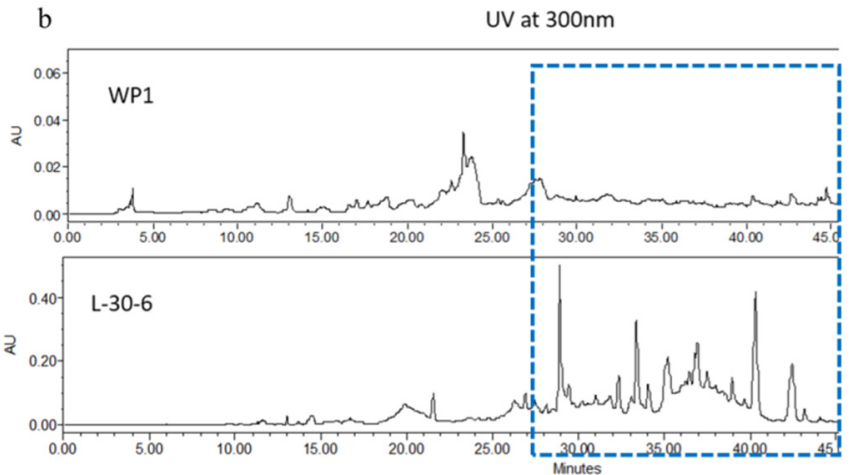

Figure 1. (a) Wild-type strain WP1 and streptomycin-resistant strain L-30-6 grown under identical conditions on ISP $_{2}$ media. (b) HPLC traces of wt-WP1 and mutant L-30-6 showing the production of new compounds (UV detection at $300 \mathrm{~nm}$ ).<smiles>[R]OCc1cc2oc(C)cc(=O)c2c(O)c1Cc1c(OC)c(CO[R])cc2c(=O)cc(C)oc12</smiles><smiles>[R]OCc1c(OC)cc2oc(C)cc(=O)c2c1O</smiles>

$7 \mathrm{R}=\mathrm{CH}_{2} \mathrm{CH}_{3}$

$8 \mathrm{R}=\mathrm{CH}_{3}$

$9 \mathrm{R}=\mathrm{H}$

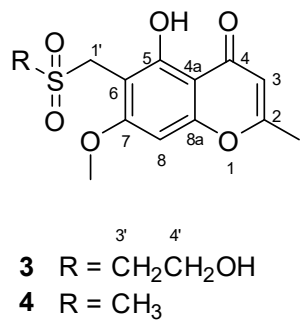<smiles>Cc1cc(O)c2c(c1)C(=O)c1cc(O)cc(O)c1C2=O</smiles>

10<smiles>COc1cc2oc(C)cc(=O)c2c(O)c1CS(C)=O</smiles>

5<smiles>COC(=O)[C@]12Oc3cccc(O)c3C(=O)[C@@]1(O)C(=O)C[C@@H](C)[C@H]2O</smiles>

6<smiles>COc1cc2oc(C)cc(=O)c2c(O)c1CS(=O)(=O)CCNC(C)=O</smiles>

11

Figure 2. Chemical structures of compounds 1-11. 


\section{Results and Discussion}

Amycolachromone A (1) displayed HRESIMS peak at $m / z$ 477.1172 [M + Na] ${ }^{+}$(calcd 477.1162) corresponding to the molecular formula $\mathrm{C}_{24} \mathrm{H}_{22} \mathrm{O}_{9}$, indicating fourteen degrees of unsaturation. Analysis of the NMR data of $\mathbf{1}$ (Table 1, see Supplementary Materials) revealed three aromatic protons at $\delta_{\mathrm{H}} 6.64(1 \mathrm{H}, \mathrm{s}, \mathrm{H}-8), 6.22\left(1 \mathrm{H}, \mathrm{s}, \mathrm{H}-3^{\prime}\right), 6.20(1 \mathrm{H}, \mathrm{s}, \mathrm{H}-3)$, two methoxy groups at $\delta_{\mathrm{H}} 3.83\left(3 \mathrm{H}, \mathrm{s}, \mathrm{CH}_{3} \mathrm{O}-7\right)$ and $3.75\left(3 \mathrm{H}, \mathrm{s}, \mathrm{CH}_{3} \mathrm{O}-7^{\prime}\right)$, two methyl groups at $\delta_{\mathrm{H}} 2.35\left(3 \mathrm{H}, \mathrm{s}, \mathrm{CH}_{3}-2\right)$ and $3.21\left(3 \mathrm{H}, \mathrm{s}, \mathrm{CH}_{3}-2^{\prime}\right)$, two methylenes at $\delta_{\mathrm{H}} 4.45(2 \mathrm{H}$, $\left.\mathrm{d}, J=4.8 \mathrm{~Hz}, \mathrm{H}-9^{\prime}\right)$ and $3.98(2 \mathrm{H}, \mathrm{s}, \mathrm{H}-9)$, two phenolic hydroxyl groups at $\delta_{\mathrm{H}} 13.13(1 \mathrm{H} \mathrm{s}$, OH-5) and $13.10\left(1 \mathrm{H} \mathrm{s}, \mathrm{OH}-5^{\prime}\right)$, a hydroxyl group at $\delta_{\mathrm{H}} 4.78\left(1 \mathrm{H}, \mathrm{t}, J=5.2 \mathrm{~Hz}, \mathrm{OH}-9^{\prime}\right)$. The ${ }^{13} \mathrm{C}$ NMR (Table 1$)$ revealed 24 carbon signals: the two carbonyls $\mathrm{C}-4\left(\delta_{\mathrm{C}} 183.2\right)$ and C- $4^{\prime}$ $\left(\delta_{\mathrm{C}} 182.5\right)$, the three aromatic carbons $\mathrm{C}-3\left(\delta_{\mathrm{C}} 108.7\right), \mathrm{C}-3^{\prime}\left(\delta_{\mathrm{C}} 108.4\right)$ and $\mathrm{C}-8\left(\delta_{\mathrm{C}} 90.6\right)$, five non-oxygenated quaternary aromatic carbons at C-4a $\left(\delta_{\mathrm{C}} 110.8\right), \mathrm{C}-6\left(\delta_{\mathrm{C}} 104.4\right), \mathrm{C}-4 \mathrm{a}^{\prime}\left(\delta_{\mathrm{C}}\right.$ $106.7), \mathrm{C}-6^{\prime}\left(\delta_{\mathrm{C}} 117.6\right)$, and $\mathrm{C}-8^{\prime}\left(\delta_{\mathrm{C}} 112.5\right)$, eight oxygenated quaternary aromatic carbons at $\mathrm{C}-2\left(\delta_{\mathrm{C}} 168.5\right), \mathrm{C}-2^{\prime}\left(\delta_{\mathrm{C}} 168.3\right), \mathrm{C}-7\left(\delta_{\mathrm{C}} 163.8\right), \mathrm{C}-7^{\prime}\left(\delta_{\mathrm{C}} 163.5\right), \mathrm{C}-5\left(\delta_{\mathrm{C}} 158.5\right), \mathrm{C}-5^{\prime}\left(\delta_{\mathrm{C}} 158.3\right)$, $\mathrm{C}-8 \mathrm{a}\left(\delta_{\mathrm{C}} 156.7\right)$, and C-8a' $\left(\delta_{\mathrm{C}} 154.8\right)$, two methoxy groups $\mathrm{CH}_{3} \mathrm{O}-7\left(\delta_{\mathrm{C}} 63.2\right)$ and $\mathrm{CH}_{3} \mathrm{O}-7^{\prime}$ $\left(\delta_{\mathrm{C}} 56.7\right)$, two methyl groups $\mathrm{CH}_{3}-2\left(\delta_{\mathrm{C}} 20.4\right)$ and $\mathrm{CH}_{3}-2^{\prime}\left(\delta_{\mathrm{C}} 20.0\right)$, and two methylenes C-9' $\left(\delta_{C} 52.1\right)$ and C-9 $\left(\delta_{C}\right.$ 16.9). Analysis of the ${ }^{1} \mathrm{H}$ and ${ }^{13} \mathrm{C}$ NMR data of 1 revealed the presence of the same 5-hydroxy-4H-chromen-4-one moiety as found in xanthones [18,19], and therefore suggested a compound comprising two xanthone building blocks.

Table $1 .{ }^{1} \mathrm{H}(500 \mathrm{MHz})$ and ${ }^{13} \mathrm{C}(125 \mathrm{MHz}) \mathrm{NMR}$ data of compounds 1 and 2 in DMSO- $d_{6}$.

\begin{tabular}{|c|c|c|c|c|}
\hline \multirow{2}{*}{ Position } & \multicolumn{2}{|l|}{1} & \multicolumn{2}{|c|}{2} \\
\hline & $\delta_{\mathbf{H}}$ & $\delta_{\mathrm{C}}$, Type & $\delta_{\mathbf{H}}$ & $\delta_{\mathrm{C}}$, Type \\
\hline 2 & & $168.5, \mathrm{C}$ & & $168.8, \mathrm{C}$ \\
\hline 3 & $6.22(\mathrm{~s}, 1 \mathrm{H})$ & 108.7, $\mathrm{CH}$ & $6.23(\mathrm{~s}, 1 \mathrm{H})$ & 108.7, $\mathrm{CH}$ \\
\hline 4 & & $183.2, \mathrm{C}$ & & $183.2, \mathrm{C}$ \\
\hline $4 a$ & & $110.8, \mathrm{C}$ & & $110.8, \mathrm{C}$ \\
\hline 5 & & $158.5, \mathrm{C}$ & & $158.9, \mathrm{C}$ \\
\hline 6 & & $104.4, \mathrm{C}$ & & $100.9, \mathrm{C}$ \\
\hline 7 & & $163.8, \mathrm{C}$ & & $164.2, \mathrm{C}$ \\
\hline 8 & $6.64(\mathrm{~s}, 1 \mathrm{H})$ & $90.6, \mathrm{CH}$ & $6.63(\mathrm{~s}, 1 \mathrm{H})$ & $90.6, \mathrm{CH}$ \\
\hline $8 a$ & & $156.7, \mathrm{C}$ & & $156.7, \mathrm{C}$ \\
\hline 9 & $3.98(\mathrm{~s}, 2 \mathrm{H})$ & $16.9, \mathrm{CH}_{2}$ & $3.98(\mathrm{~s}, 2 \mathrm{H})$ & $16.9, \mathrm{CH}_{2}$ \\
\hline $2^{\prime}$ & & $168.3, \mathrm{C}$ & & $168.2, \mathrm{C}$ \\
\hline $3^{\prime}$ & $6.20(\mathrm{~s}, 1 \mathrm{H})$ & $108.4, \mathrm{CH}$ & $6.22(\mathrm{~s}, 1 \mathrm{H})$ & $108.5, \mathrm{CH}$ \\
\hline $4^{\prime}$ & & $182.5, \mathrm{C}$ & & $182.4, \mathrm{C}$ \\
\hline $4 a^{\prime}$ & & $106.7, \mathrm{C}$ & & $106.7, \mathrm{C}$ \\
\hline $5^{\prime}$ & & $158.3, \mathrm{C}$ & & $158.6, \mathrm{C}$ \\
\hline $6^{\prime}$ & & $117.6, \mathrm{C}$ & & $114.1, \mathrm{C}$ \\
\hline $7^{\prime}$ & & $163.5, \mathrm{C}$ & & $163.4, \mathrm{C}$ \\
\hline $8^{\prime}$ & & $112.2, \mathrm{C}$ & & $112.5, \mathrm{C}$ \\
\hline $8 a^{\prime}$ & & $154.8, \mathrm{C}$ & & $154.8, \mathrm{C}$ \\
\hline $9^{\prime}$ & $4.45(\mathrm{~d}, J=4.8 \mathrm{~Hz}, 2 \mathrm{H})$ & $52.1, \mathrm{CH}_{2}$ & $4.35(\mathrm{~s}, 2 \mathrm{H})$ & $63.2, \mathrm{CH}_{2}$ \\
\hline $2-\mathrm{CH}_{3}$ & $2.35(\mathrm{~s}, 3 \mathrm{H})$ & $20.4, \mathrm{CH}_{3}$ & $2.35(\mathrm{~s}, 3 \mathrm{H})$ & $20.4, \mathrm{CH}_{3}$ \\
\hline $7-\mathrm{OCH}_{3}$ & $3.83(\mathrm{~s}, 3 \mathrm{H})$ & $63.2, \mathrm{CH} 3$ & $3.82(\mathrm{~s}, 3 \mathrm{H})$ & $62.5, \mathrm{CH} 3$ \\
\hline $2^{\prime}-\mathrm{CH}_{3}$ & $2.21(\mathrm{~s}, 3 \mathrm{H})$ & $20.0, \mathrm{CH}_{3}$ & $2.21(\mathrm{~s}, 3 \mathrm{H})$ & $20.0, \mathrm{CH}_{3}$ \\
\hline $7^{\prime}-\mathrm{OCH}_{3}$ & $3.75(\mathrm{~s}, 3 \mathrm{H})$ & $56.7, \mathrm{CH}_{3}$ & $3.76(\mathrm{~s}, 3 \mathrm{H})$ & $56.6, \mathrm{CH}_{3}$ \\
\hline $9^{\prime}-\mathrm{OCH}_{3}$ & & & $3.29(\mathrm{~s}, 3 \mathrm{H})$ & $57.7, \mathrm{CH}_{3}$ \\
\hline $5-\mathrm{OH}$ & $13.13(\mathrm{~s}, 1 \mathrm{H})$ & & $13.21(\mathrm{~s}, 1 \mathrm{H})$ & \\
\hline $5^{\prime}-\mathrm{OH}$ & $13.10(\mathrm{~s}, 1 \mathrm{H})$ & & $13.11(\mathrm{~s}, 1 \mathrm{H})$ & \\
\hline $9^{\prime}-\mathrm{OH}$ & $4.78(\mathrm{t}, J=5.2 \mathrm{~Hz}, 1 \mathrm{H})$ & & & \\
\hline
\end{tabular}

${ }^{1} \mathrm{H}-{ }^{1} \mathrm{H}$ COSY correlations were observed from $\mathrm{H}-9{ }^{\prime}$ to OH-9'. Further confirmation was found for HMBC correlations of 5-OH to C-5, C-6, 4a; H-8 to C-6, C-4a, C-8a; H-3 to $\mathrm{C}-2 ; 2-\mathrm{CH}_{3}$ to $\mathrm{C}-2, \mathrm{C}-3$, indicating the same Eugenin. $\mathrm{HMBC}$ correlations from $5^{\prime}-\mathrm{OH}$ to $\mathrm{C}-5^{\prime}, \mathrm{C}-6^{\prime}, 4 \mathrm{a}^{\prime} ; \mathrm{H}-3^{\prime}$ to $\mathrm{C}-2^{\prime} ; 2^{\prime}-\mathrm{CH}_{3}$ to $\mathrm{C}-2^{\prime}, \mathrm{C}-3^{\prime} ; \mathrm{H}-9^{\prime}$ to $\mathrm{C}-5^{\prime}, \mathrm{C}-6^{\prime}, \mathrm{C}-7^{\prime}$, indicated the 
same 6-Hydroxymethyleugenin (10) [20]. HMBC correlations from H-9 to C-7, C-5, C-4a, C $8^{\prime}, C-7, C-8 a^{\prime}$, indicated that Eugenin and 6-hydroxymethyleugenin are linked with C-9. Selected key correlations in the observed NMR spectrum are shown in Figure 3. On the basis of these results, the structure of compound $\mathbf{1}$ was established as shown.

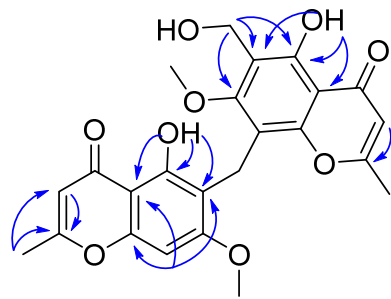

1

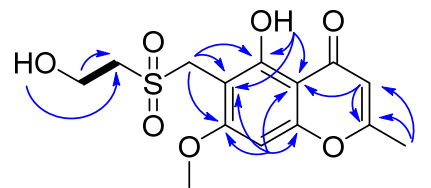

3

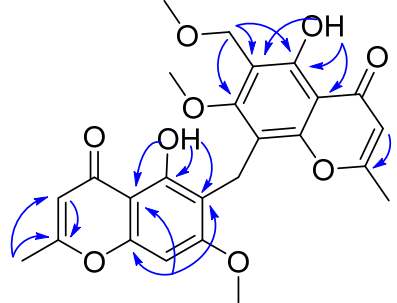

2

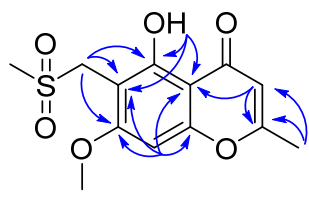

4

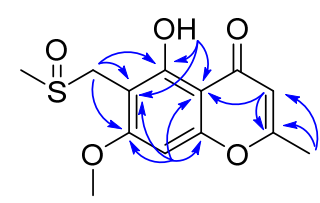

5

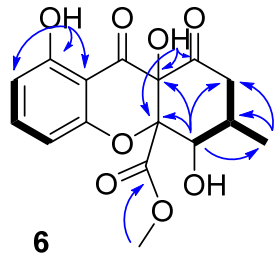

6

Figure 3. Key HMBC and COSY correlations of compounds 1-6.

Amycolachromone B (2) displayed HRESIMS peak at $m / z 469.1502[\mathrm{M}+\mathrm{H}]^{+}$(calcd 469.1499), $m / z 491.1333[\mathrm{M}+\mathrm{Na}]^{+}$(calcd 469.1318), corresponding to the molecular formula $\mathrm{C}_{25} \mathrm{H}_{24} \mathrm{O}_{9}$ (fourteen degrees of unsaturation). Analysis of the NMR data of 2 (Table 1) revealed for three aromatic protons at $\delta_{\mathrm{H}} 6.64(1 \mathrm{H}, \mathrm{s}, \mathrm{H}-8), 6.22\left(1 \mathrm{H}, \mathrm{s}, \mathrm{H}-3^{\prime}\right), 6.23(1 \mathrm{H}$, $\mathrm{s}, \mathrm{H}-3)$, two methoxy groups at $\delta_{\mathrm{H}} 3.82\left(3 \mathrm{H}, \mathrm{s}, \mathrm{CH}_{3} \mathrm{O}-7\right)$ and $3.76\left(3 \mathrm{H}, \mathrm{s}, \mathrm{CH}_{3} \mathrm{O}-7^{\prime}\right)$, two methyl groups at $\delta_{\mathrm{H}} 2.22\left(3 \mathrm{H}, \mathrm{s}, \mathrm{CH}_{3}-2\right)$ and $3.37\left(3 \mathrm{H}, \mathrm{s}, \mathrm{CH}_{3}-2^{\prime}\right)$, two methylene at $\delta_{\mathrm{H}}$ $4.35\left(2 \mathrm{H}, \mathrm{s}, \mathrm{H}-9^{\prime}\right)$ and $3.98(2 \mathrm{H}, \mathrm{s}, \mathrm{H}-9)$, two phenolic hydroxyl groups at $\delta_{\mathrm{H}} 13.21(1 \mathrm{H} \mathrm{s}$, $\mathrm{OH}-5)$ and $13.11\left(1 \mathrm{H} \mathrm{s}, \mathrm{OH}-5^{\prime}\right)$. The ${ }^{13} \mathrm{C}$ NMR (Table 1$)$ revealed 25 carbon signals: the two carbonyl group C-4 $\left(\delta_{\mathrm{C}} 183.2\right), \mathrm{C}-4^{\prime}\left(\delta_{\mathrm{C}} 182.4\right)$, three aromatic carbon $\mathrm{C}-3\left(\delta_{\mathrm{C}} 108.7\right), \mathrm{C}-3^{\prime}$ $\left(\delta_{\mathrm{C}} 108.5\right)$ and $\mathrm{C}-8\left(\delta_{\mathrm{C}} 90.6\right)$, five nonoxygenated quaternary aromatic carbons at $\mathrm{C}-4 \mathrm{a}\left(\delta_{\mathrm{C}}\right.$ $110.8), \mathrm{C}-6\left(\delta_{\mathrm{C}} 100.9\right), \mathrm{C}-4 \mathrm{a}^{\prime}\left(\delta_{\mathrm{C}} 106.7\right), \mathrm{C}-6^{\prime}\left(\delta_{\mathrm{C}} 114.1\right)$, and $\mathrm{C}-8^{\prime}\left(\delta_{\mathrm{C}} 112.5\right)$, eight oxygenated quaternary aromatic carbons at $\mathrm{C}-2\left(\delta_{\mathrm{C}} 168.8\right), \mathrm{C}-2^{\prime}\left(\delta_{\mathrm{C}} 168.2\right), \mathrm{C}-7\left(\delta_{\mathrm{C}} 164.2\right), \mathrm{C}-7^{\prime}\left(\delta_{\mathrm{C}} 163.4\right)$, $\mathrm{C}-5\left(\delta_{\mathrm{C}} 158.9\right), \mathrm{C}-5^{\prime}\left(\delta_{\mathrm{C}} 158.6\right), \mathrm{C}-8 \mathrm{a}\left(\delta_{\mathrm{C}} 156.7\right)$, and C-8a' $\left(\delta_{\mathrm{C}} 154.8\right)$, three methoxy groups $\mathrm{CH}_{3} \mathrm{O}-7\left(\delta_{\mathrm{C}} 62.5\right), \mathrm{CH}_{3} \mathrm{O}-9^{\prime}\left(\delta_{\mathrm{C}} 57.7\right)$, and $\mathrm{CH}_{3} \mathrm{O}-7^{\prime}\left(\delta_{\mathrm{C}} 56.6\right)$, two methyl groups $\mathrm{CH}_{3}-2\left(\delta_{\mathrm{C}}\right.$ $20.4)$ and $\mathrm{CH}_{3}-2^{\prime}\left(\delta_{\mathrm{C}} 20.0\right)$, two methylene $\mathrm{C}^{-9} 9^{\prime}\left(\delta_{\mathrm{C}} 63.2\right)$ and $\mathrm{C}-9\left(\delta_{\mathrm{C}} 16.9\right)$. Analysis of the ${ }^{1} \mathrm{H}$ and ${ }^{13} \mathrm{C}$ NMR data of 2 revealed the presence of the same 5-hydroxy-4H-chromen-4-one moiety as found in xanthones $[18,19]$, and comprised two xanthones. In contrast, the NMR data of $\mathbf{2}$ showed them to be nearly identical except for a methoxy group linked with C-9'. Further confirmation was found for HMBC correlations of 5-OH to C-5, C-6, 4a; H-8 to C-6, C-4a, C-8a, C-7; H-3 to C-2; 2-CH $\mathrm{CH}_{3}$ to C-2, C-3, indicated that same as Eugenin [20]. HMBC correlations from $5^{\prime}-\mathrm{OH}$ to $\mathrm{C}-5^{\prime}, \mathrm{C}-6^{\prime}, 4 \mathrm{a}^{\prime} ; \mathrm{H}-3^{\prime}$ to $\mathrm{C}-2^{\prime} ; 2^{\prime}-\mathrm{CH}_{3}$ to $\mathrm{C}-2^{\prime}, \mathrm{C}-3^{\prime} ; \mathrm{H}-9^{\prime}$ to $\mathrm{C}-5^{\prime}, \mathrm{C}-$ $6^{\prime}, \mathrm{C}-7^{\prime}$, indicated that same as 6-Methoxymethyleugenin (9) [21]. HMBC correlations from H-9 to C-7, C-5, C-4a, C 8' , C-7, C-8a', indicated that Eugenin and Methoxymethyleugenin are linked with C-9. Selected key correlations in the observed NMR spectrum are shown in Figure 3. On the basis of these results, the structure of compound 2 was established as shown.

Amycolachromone C (3) displayed HRESIMS ion at $m / z 351.0515[\mathrm{M}+\mathrm{Na}]^{+}$(calcd 351.0514), corresponding to the molecular formula $\mathrm{C}_{14} \mathrm{H}_{16} \mathrm{O}_{7} \mathrm{~S}$, indicating nine degrees of unsaturation. Analysis of the NMR data of 3 (Table 2) revealed two aromatic protons at $\delta_{\mathrm{H}} 6.78(1 \mathrm{H}, \mathrm{s}, \mathrm{H}-8), 6.32(1 \mathrm{H}, \mathrm{s}, \mathrm{H}-3)$, a methoxy group at $\delta_{\mathrm{H}} 3.90\left(3 \mathrm{H}, \mathrm{s}, \mathrm{CH}_{3} \mathrm{O}-7\right)$, a methyl group at $\delta_{\mathrm{H}} 2.39\left(3 \mathrm{H}, \mathrm{s}, \mathrm{CH}_{3}-2\right)$, three methylenes at $\delta_{\mathrm{H}} 4.39\left(2 \mathrm{H}, \mathrm{s}, \mathrm{H}-1^{\prime}\right), \delta_{\mathrm{H}} 3.80$ 
$\left(2 \mathrm{H}, \mathrm{q}, J=6.1 \mathrm{~Hz}, \mathrm{H}-4^{\prime}\right)$, and $3.21\left(2 \mathrm{H}, \mathrm{t}, J=6.3, \mathrm{H}-3^{\prime}\right)$, a phenolic hydroxyl group at $\delta_{\mathrm{H}} 11.40$ $(1 \mathrm{H} \mathrm{s}, \mathrm{OH}-5)$, and a hydroxyl group at $\delta_{\mathrm{H}} 5.03\left(1 \mathrm{H}, \mathrm{t}, J=5.4 \mathrm{~Hz}, 1 \mathrm{H}, \mathrm{OH}-4^{\prime}\right)$. Examination of the ${ }^{13} \mathrm{C}$ NMR spectrum (Table 2$)$ revealed 14 carbon signals: a carbonyl group C-4 $\left(\delta_{\mathrm{C}}\right.$ 182.4), the two aromatic carbons $C-3\left(\delta_{C} 108.9\right)$ and $C-8\left(\delta_{C} 91.3\right)$, three non-oxygenated quaternary aromatic carbons at C-8a $\left(\delta_{\mathrm{C}} 158.2\right), \mathrm{C}-4 \mathrm{a}\left(\delta_{\mathrm{C}} 104.6\right)$, and C-6 $\left(\delta_{\mathrm{C}} 101.0\right)$, and three oxygenated quaternary aromatic carbons at $\mathrm{C}-2\left(\delta_{\mathrm{C}} 168.9\right), \mathrm{C}-5\left(\delta_{\mathrm{C}} 159.9\right)$, and $\mathrm{C}-7\left(\delta_{\mathrm{C}} 163.9\right)$ and the methylene $\mathrm{C}-1^{\prime}\left(\delta_{\mathrm{C}} 49.3\right)$. Analysis of the ${ }^{1} \mathrm{H}$ and ${ }^{13} \mathrm{C}$ NMR data of 2 revealed the presence of the same 5-hydroxy-4H-chromen-4-one moiety as found in xanthones [18,19].

Table 2. ${ }^{1} \mathrm{H}(500 \mathrm{MHz})$ and ${ }^{13} \mathrm{C}(125 \mathrm{MHz})$ NMR data of compounds 3-5 in DMSO- $d_{6}$.

\begin{tabular}{ccccccc}
\hline \multirow{2}{*}{ Position } & \multicolumn{2}{c}{3} & \multicolumn{2}{c}{4} & \multicolumn{2}{c}{5} \\
\cline { 2 - 7 } & $\delta_{\mathbf{H}}$ & $\delta_{\mathrm{C}}$, Type & $\delta_{\mathbf{H}}$ & $\delta_{\mathbf{C}}$, Type & $\delta_{\mathbf{H}}$ & $\delta_{\mathbf{C}}$, Type \\
\hline 2 & & $168.9, \mathrm{qC}$ & & $168.7, \mathrm{qC}$ & & $168.8, \mathrm{qC}$ \\
3 & $6.31, \mathrm{~s}$ & $108.9, \mathrm{CH}$ & $6.30, \mathrm{~s}$ & $108.9, \mathrm{CH}$ & $6.29, \mathrm{~s}$ & $108.9, \mathrm{CH}$ \\
4 & & $182.4, \mathrm{qC}$ & & $182.3, \mathrm{qC}$ & & $182.3, \mathrm{qC}$ \\
$4 \mathrm{a}$ & & $104.6, \mathrm{qC}$ & & $104.7, \mathrm{qC}$ & & $104.7, \mathrm{qC}$ \\
5 & & $159.9, \mathrm{qC}$ & & $159.1, \mathrm{qC}$ & & $159.6, \mathrm{qC}$ \\
6 & & $101.0, \mathrm{qC}$ & & $101.2, \mathrm{qC}$ & & $102.3, \mathrm{qC}$ \\
7 & & $163.9, \mathrm{qC}$ & & $163.7, \mathrm{qC}$ & & $163.6, \mathrm{qC}$ \\
8 & $6.78, \mathrm{~s}$ & $91.3, \mathrm{CH}$ & $6.76, \mathrm{~s}$ & $91.1, \mathrm{CH}$ & $6.76, \mathrm{~s}$ & $91.2, \mathrm{CH}$ \\
$8 \mathrm{a}$ & & $158.2, \mathrm{qC}$ & & $158.2, \mathrm{qC}$ & & $157.8, \mathrm{qC}$ \\
$1^{\prime}$ & $4.39, \mathrm{~s}$ & $49.3, \mathrm{CH}_{2}$ & $4.33, \mathrm{~s}$ & $49.4, \mathrm{CH}$ & $3.99, \mathrm{~d},(6.7)$ & $48.4, \mathrm{CH}_{2}$ \\
$3^{\prime}$ & $3.21, \mathrm{t}(6.3)$ & $56.6, \mathrm{CH}_{2}$ & $2.91, \mathrm{~s}$ & $42.0, \mathrm{CH}$ & $2.54, \mathrm{~s}$ & $39.1, \mathrm{CH}_{3}$ \\
$4^{\prime}$ & $3.80, \mathrm{q}(6.1)$ & $55.3, \mathrm{CH}_{2}$ & & & & \\
$\mathrm{OH}^{\prime} 5$ & $13.40, \mathrm{~s}$ & & & & & \\
$\mathrm{OH}_{-4}^{\prime}$ & $5.03, \mathrm{t}(5.4)$ & & & & & \\
$\mathrm{OCH}_{3}-7$ & $3.90, \mathrm{~s}$ & $57.2, \mathrm{CH}_{3}$ & $3.90, \mathrm{~s}$ & $57.2, \mathrm{CH}_{3}$ & $3.90, \mathrm{~s}$ & $57.2, \mathrm{CH}_{3}$ \\
$\mathrm{CH}_{3}-2$ & $2.39, \mathrm{~s}$ & $20.4, \mathrm{CH}_{3}$ & $2.39, \mathrm{~s}$ & $20.4, \mathrm{CH}_{3}$ & $2.39, \mathrm{~s}$ & $20.4, \mathrm{CH}_{3}$ \\
\hline
\end{tabular}

In the ${ }^{1} \mathrm{H}-{ }^{1} \mathrm{H}$ COSY spectrum, there were correlations from $\mathrm{H}-4^{\prime}$ to $\mathrm{OH}-5^{\prime}$ and $\mathrm{H}-3^{\prime}$. According to the $\mathrm{HMBC}$, there were correlations from $\mathrm{H}-1^{\prime}$ to $\mathrm{C}-6, \mathrm{C}-5$, and $\mathrm{C}-7, \mathrm{H}-4^{\prime}$ to $\mathrm{C}-3^{\prime}, \mathrm{OH}-4^{\prime}$ to $\mathrm{C}-3^{\prime}$. The sulfur atom present in 3 was shown to be attached at $\mathrm{C}-1^{\prime}$ and $\mathrm{C}-3^{\prime}$, indicated that $\mathrm{C}-1^{\prime}$ was attached at $\mathrm{C}-6$. Further confirmation was found for HMBC correlations of OH-5 to C-4a, C-6, C-5; $\mathrm{CH}_{3}-2$ to C-3, C-2; $\mathrm{CH}_{3} \mathrm{O}-7$ to $\mathrm{C} 7, \mathrm{H}-3$ to $\mathrm{CH}_{3}-2$, C-4a, C-2; H-8 to C-4a, C-6, C-8a, C-7, C-4, a hydroxyl group could be located at C-5, a methoxy groups could be located at C-7, a methyl group could be located at C-2. Selected key correlations in the observed NMR spectrum are shown in Figure 3. On the basis of these results, the structure of compound 3 was established as shown.

Amycolachromone D (4) displayed HRESIMS peak at $m / z 321.0406[\mathrm{M}+\mathrm{Na}]^{+}(\mathrm{calcd}$ 321.0409), corresponding to the molecular formula $\mathrm{C}_{13} \mathrm{H}_{14} \mathrm{O}_{6} \mathrm{~S}$ (nine degrees of unsaturation). Analysis of the NMR data of 4 (Table 2) revealed for two aromatic protons at $\delta_{\mathrm{H}} 6.76(1 \mathrm{H}, \mathrm{s}, \mathrm{H}-8), 6.30(1 \mathrm{H}, \mathrm{s}, \mathrm{H}-3)$, a methoxy groups at $\delta_{\mathrm{H}} 3.90\left(3 \mathrm{H}, \mathrm{s}, \mathrm{CH}_{3} \mathrm{O}-7\right)$, two methyl groups at $\delta_{\mathrm{H}} 2.91\left(3 \mathrm{H}, \mathrm{s}, \mathrm{H}-3^{\prime}\right)$ and $2.39\left(3 \mathrm{H}, \mathrm{s}, \mathrm{CH}_{3}-2\right)$, a methylene group at $\delta_{\mathrm{H}}$ $4.33\left(2 \mathrm{H}, \mathrm{s}, \mathrm{H}-1^{\prime}\right)$. The ${ }^{13} \mathrm{C}$ NMR (Table 2$)$ revealed 13 carbon signals: a carbonyl group $\mathrm{C}-4\left(\delta_{\mathrm{C}} 182.3\right)$, two aromatic carbon $\mathrm{C}-3\left(\delta_{\mathrm{C}} 108.9\right)$ and C-8 $\left(\delta_{\mathrm{C}} 91.1\right)$, three nonoxygenated quaternary aromatic carbons at C-8a $\left(\delta_{\mathrm{C}} 158.2\right), \mathrm{C}-4 \mathrm{a}\left(\delta_{\mathrm{C}} 104.7\right)$, and C-6 $\left(\delta_{\mathrm{C}} 101.2\right)$, three oxygenated quaternary aromatic carbons at $\mathrm{C}-2\left(\delta_{\mathrm{C}} 168.7\right), \mathrm{C}-5\left(\delta_{\mathrm{C}} 159.1\right)$, and $\mathrm{C}-7\left(\delta_{\mathrm{C}} 163.7\right)$, a methoxy groups $\mathrm{CH}_{3} \mathrm{O}-7\left(\delta_{\mathrm{C}} 57.2\right)$, two methyl groups $\mathrm{C}-3^{\prime}\left(\delta_{\mathrm{C}} 42.0\right)$ and $\mathrm{CH}_{3}-2\left(\delta_{\mathrm{C}} 20.4\right)$, a methylene group $\mathrm{C}-1^{\prime}\left(\delta_{\mathrm{C}} 49.4\right)$. Analysis of the ${ }^{1} \mathrm{H}$ and ${ }^{13} \mathrm{C}$ NMR data of 4 revealed the presence of the same 5-hydroxy-4H-chromen-4-one moiety as found in xanthones $[18,19]$. A side-by-side comparison of the NMR spectroscopic data with those of $\mathbf{3}$ showed them to be nearly identical except for the final hydroxymethyl unit on the side chain.

According to the HMBC correlations from $\mathrm{H}-1^{\prime}$ to $\mathrm{C}-6, \mathrm{C}-5$ and $\mathrm{C}-7$, the sulfur atom present in 4 was shown to be attached at $C-1^{\prime}$ and $C-3^{\prime}$, indicating that $C-1^{\prime}$ was attached at C-6, Further confirmation was found for $\mathrm{HMBC}$ correlations of $\mathrm{CH}_{3} \mathrm{O}-7$ to $\mathrm{C}$; $\mathrm{H}-3$ to 
$\mathrm{CH}_{3}-2, \mathrm{C}-4 \mathrm{a}, \mathrm{C}-2 ; \mathrm{H}-8$ to $\mathrm{C}-4 \mathrm{a}, \mathrm{C}-6, \mathrm{C}-8 \mathrm{a}, \mathrm{C}-7, \mathrm{C}-4$, a methoxy group could be located at C-7 and a methyl group could be located at C-2. Selected key correlations in the observed NMR spectrum are shown in Figure 3. On the basis of these results, the structure of compound 4 was established as shown.

Amycolachromone E (5) displayed HRESIMS peak at $m / z 305.0462[\mathrm{M}+\mathrm{Na}]^{+}$(calcd 305.0460), corresponding to the molecular formula $\mathrm{C}_{13} \mathrm{H}_{14} \mathrm{O}_{5} \mathrm{~S}$ (eight degrees of unsaturation). Analysis of the NMR data of 5 (Table 2) revealed for two aromatic protons at $\delta_{\mathrm{H}} 6.76(1 \mathrm{H}, \mathrm{s}, \mathrm{H}-8), 6.29(1 \mathrm{H}, \mathrm{s}, \mathrm{H}-3)$, a methoxy groups at $\delta_{\mathrm{H}} 3.90\left(3 \mathrm{H}, \mathrm{s}, \mathrm{CH}_{3} \mathrm{O}-7\right)$, two methyl groups at $\delta_{\mathrm{H}} 2.54\left(3 \mathrm{H}, \mathrm{s}, \mathrm{H}-3^{\prime}\right)$ and $2.39\left(3 \mathrm{H}, \mathrm{s}, \mathrm{CH}_{3}-2\right)$ and a methylene group at $\delta_{\mathrm{H}} 3.99\left(2 \mathrm{H}, \mathrm{d}, J=6.7 \mathrm{~Hz}, \mathrm{H}-1^{\prime}\right)$. The ${ }^{13} \mathrm{C}$ NMR (Table 2$)$ revealed 13 carbon signals: a carbonyl group $\mathrm{C}-4\left(\delta_{\mathrm{C}} 182.3\right)$, two aromatic carbon $\mathrm{C}-3\left(\delta_{\mathrm{C}} 108.9\right)$ and $\mathrm{C}-8\left(\delta_{\mathrm{C}} 91.2\right)$, three nonoxygenated quaternary aromatic carbons at C-8a $\left(\delta_{\mathrm{C}} 157.8\right), \mathrm{C}-4 \mathrm{a}\left(\delta_{\mathrm{C}} 104.7\right)$, and C-6 $\left(\delta_{\mathrm{C}} 102.3\right)$, three oxygenated quaternary aromatic carbons at $\mathrm{C}-2\left(\delta_{\mathrm{C}} 168.8\right), \mathrm{C}-5\left(\delta_{\mathrm{C}} 159.6\right)$, and $\mathrm{C}-7\left(\delta_{\mathrm{C}} 163.6\right)$, a methoxy groups $\mathrm{CH}_{3} \mathrm{O}-7\left(\delta_{\mathrm{C}} 57.2\right)$, two methyl groups $\mathrm{C}-3^{\prime}\left(\delta_{\mathrm{C}} 39.1\right)$ and $\mathrm{CH}_{3}-2\left(\delta_{\mathrm{C}} 20.4\right)$, a methylene group $\mathrm{C}-1^{\prime}\left(\delta_{\mathrm{C}} 48.4\right)$. Analysis of the ${ }^{1} \mathrm{H}$ and ${ }^{13} \mathrm{C}$ NMR data of 5 revealed the presence of the same 5-hydroxy-4H-chromen-4-one moiety as found in xanthones $[18,19]$. A side-by-side comparison of the NMR spectroscopic data with those of 3 showed them to be nearly identical except for the final sulfur monoxide unit on the side chain.

According to the HMBC correlations from $\mathrm{H}-\mathrm{1}^{\prime}$ to $\mathrm{C}-6, \mathrm{C}-5$ and $\mathrm{C}-7, \mathrm{H}-3^{\prime}$ to $\mathrm{C}-\mathrm{1}^{\prime}$, the sulfur atom present in 5 was shown to be attached at $C-1^{\prime}$ and $C-3^{\prime}$, indicating that $C-1^{\prime}$ was attached at C-6, Further confirmation was found for $\mathrm{HMBC}$ correlations of $\mathrm{CH}_{3} \mathrm{O}-7$ to C7; $\mathrm{H}-3$ to $\mathrm{CH}_{3}-2, \mathrm{C}-4 \mathrm{a}, \mathrm{C}-2$; $\mathrm{H}-8$ to $\mathrm{C}-4 \mathrm{a}, \mathrm{C}-6, \mathrm{C}-8 \mathrm{a}, \mathrm{C}-7$ and $\mathrm{C}-4$, a methoxy group could be located at C-7, a methyl group could be located at C-2. Selected key correlations in the observed NMR spectrum are shown in Figure 3. On the basis of these results, the structure of compound 5 was established as shown.

Amycolachromone F (6), $[\alpha]_{D}^{25}-54$ (c 0.1, MeOH), displayed HRESIMS peak at $m / z$ $337.0915[\mathrm{M}+\mathrm{H}]^{+}$(calcd 337.0923), corresponding to the molecular formula $\mathrm{C}_{16} \mathrm{H}_{16} \mathrm{O}_{8}$ (nine degrees of unsaturation). Analysis of the ${ }^{1} \mathrm{H}$ data of 6 (Table 3 ) revealed resonance for three aromatic protons at $\delta_{\mathrm{H}} 7.52(1 \mathrm{H}, \mathrm{t}, J=8.3 \mathrm{~Hz}, \mathrm{H}-3), 6.60(1 \mathrm{H}, \mathrm{d}, J=8.3 \mathrm{~Hz}, \mathrm{H}-4)$, $6.53(1 \mathrm{H}, \mathrm{d}, J=8.3 \mathrm{~Hz}, \mathrm{H}-2)$, a methoxy group at $\delta_{\mathrm{H}} 3.50(3 \mathrm{H}, \mathrm{s}, \mathrm{H}-15)$, a methyl group at $\delta_{\mathrm{H}} 1.06(3 \mathrm{H}, \mathrm{d}, J=6.4 \mathrm{~Hz}, \mathrm{H}-16)$, a methylene at $\delta_{\mathrm{H}} 2.81(1 \mathrm{H}, \mathrm{dd}, J=14.4,12.9 \mathrm{~Hz}, \mathrm{H}-9 \mathrm{a})$ and $2.25(1 \mathrm{H}, \mathrm{dd}, J=14.5,5.3 \mathrm{~Hz}, \mathrm{H}-9 \mathrm{~b})$, a oxygenated methine at $\delta_{\mathrm{H}} 4.20(1 \mathrm{H}, \mathrm{dd}, J=10.5$, $6.0 \mathrm{~Hz}, \mathrm{H}-7)$, a methine at $\delta_{\mathrm{H}} 1.97-1.86(1 \mathrm{H}, \mathrm{m}, \mathrm{H}-8)$, three hydroxyl groups at $\delta_{\mathrm{H}} 11.35(1 \mathrm{H}$ s, OH-1), $8.09(1 \mathrm{H}, \mathrm{s}, \mathrm{OH}-11)$, and $5.91(1 \mathrm{H}, \mathrm{d}, J=6.0 \mathrm{~Hz}, \mathrm{OH}-7)$. The ${ }^{13} \mathrm{C}$ NMR (Table 3) revealed sixteen carbon signals: three carbonyl group $\mathrm{C}-10\left(\delta_{\mathrm{C}} 198.6\right), \mathrm{C}-12\left(\delta_{\mathrm{C}} 191.8\right)$ and C-14 $\left(\delta_{\mathrm{C}} 168.5\right)$, three aromatic carbon C-3 $\left(\delta_{\mathrm{C}} 138.7\right), \mathrm{C}-2\left(\delta_{\mathrm{C}} 109.5\right)$, and C-4 $\left(\delta_{\mathrm{C}} 107.4\right)$, a nonoxygenated quaternary aromatic carbons at $C-13\left(\delta_{C} 106.5\right)$, two oxygenated quaternary aromatic carbons at C-1 $\left(\delta_{\mathrm{C}} 161.9\right)$ and C-5 $\left(\delta_{\mathrm{C}} 158.9\right)$, two sp ${ }^{3}$-quaternary carbon C-11 $\left(\delta_{\mathrm{C}}\right.$ 90.0) and C-6 $\left(\delta_{C} 73.0\right)$, a methoxy group C-15 $\left(\delta_{C} 52.7\right)$, a methyl group C-16 $\left(\delta_{C} 18.6\right)$, an oxygenated methine $C-7\left(\delta_{C} 71.8\right)$, a methine $C-8\left(\delta_{C} 31.1\right)$ and a methylene $C-9$ group $\left(\delta_{\mathrm{C}} 43.1\right)$. Analysis of the ${ }^{1} \mathrm{H}$ and ${ }^{13} \mathrm{C}$ NMR data of 6 revealed the presence of the same 5-hydroxy-4H-chromen-4-one moiety as found in xanthones $[18,19]$. In the ${ }^{1} \mathrm{H}-{ }^{1} \mathrm{H} \mathrm{COSY}$ spectrum, the correlations from $\mathrm{H}-7$ to $\mathrm{H}-8$ and $\mathrm{OH}-7$, from $\mathrm{H}-8$ to $\mathrm{H}-9$ and $\mathrm{H}-16$. Further confirmation was found for HMBC correlations of $\mathrm{H}-7$ to $\mathrm{C}-16, \mathrm{C}-6, \mathrm{C}-11$ and $\mathrm{C}-9$; $\mathrm{H}_{3}-16$ to C-7, C-8 and C-9, indicated that C-16 was attached to C-8, and $\mathrm{OH}-7$ was located at C-7. $\mathrm{HMBC}$ correlations from the $\mathrm{O}$-methyl proton signal $\mathrm{H}_{3}-15$ to the carboxylic carbon $\mathrm{C}-14$ confirmed that the $\mathrm{O}$-methyl group was located at $\mathrm{C}-14$. HMBC correlations from $\mathrm{OH}-11$ to $\mathrm{C}-11, \mathrm{C}-6$ and $\mathrm{C}-10, \mathrm{OH}-1$ to $\mathrm{C}-2, \mathrm{C}-13$ and $\mathrm{C}-1$ indicated that $\mathrm{OH}-1$ and $\mathrm{OH}-11$ were attached to C-1 and C-11, respectively [22,23]. Selected key correlations in the observed NMR spectrum are shown in Figure 3. Thus, the planar structure of 6 was established. Moreover, the relative configuration of 6 was established to be $6 R^{*}, 7 S^{*}, 8 R^{*}$ and $11 R^{*}$ by X-ray crystallography using Mo Ka radiation (Figure 4). 
Table 3. ${ }^{1} \mathrm{H}(500 \mathrm{MHz})$ and ${ }^{13} \mathrm{C}(125 \mathrm{MHz}) \mathrm{NMR}$ data of compound 6 in DMSO- $d_{6}$.

\begin{tabular}{|c|c|c|}
\hline \multirow{2}{*}{ Position } & \multicolumn{2}{|c|}{6} \\
\hline & $\delta_{\mathbf{H}}$ & $\delta_{\mathrm{C}}$, Type \\
\hline 1 & & $161.9, \mathrm{qC}$ \\
\hline 2 & $6.53, \mathrm{~d}(8.3)$ & $109.5, \mathrm{CH}$ \\
\hline 3 & $7.52, \mathrm{t}(8.3)$ & $138.7, \mathrm{CH}$ \\
\hline 4 & $6.60, \mathrm{~d}(8.3)$ & 107.4, $\mathrm{CH}$ \\
\hline 5 & & $158.9, \mathrm{qC}$ \\
\hline 6 & & $73.0, \mathrm{qC}$ \\
\hline 7 & $4.20, \mathrm{dd}(10.5,6.0)$ & $71.8, \mathrm{CH}$ \\
\hline 8 & $1.97-1.86, \mathrm{~m}$ & $31.1, \mathrm{CH}$ \\
\hline 9 & $\begin{array}{c}2.81, \mathrm{dd}(14.4,12.9) \\
2.25 \mathrm{dd}(14.5,5.3)\end{array}$ & $43.1, \mathrm{CH}_{2}$ \\
\hline 10 & & $198.6, \mathrm{qC}$ \\
\hline 11 & & $90.0, \mathrm{qC}$ \\
\hline 12 & & $191.8, \mathrm{qC}$ \\
\hline 13 & & $106.5, \mathrm{qC}$ \\
\hline 14 & & $168.5, \mathrm{qC}$ \\
\hline 15 & $3.50, \mathrm{~s}$ & 52.7, $\mathrm{CH}_{3}$ \\
\hline 16 & $1.06, \mathrm{~d}(6.4)$ & $18.6, \mathrm{CH}_{3}$ \\
\hline $\mathrm{OH}-1$ & $11.35, \mathrm{~s}$ & \\
\hline $\mathrm{OH}-7$ & $5.91, \mathrm{~d}(6.0)$ & \\
\hline $\mathrm{OH}-11$ & $8.09, \mathrm{~s}$ & \\
\hline
\end{tabular}

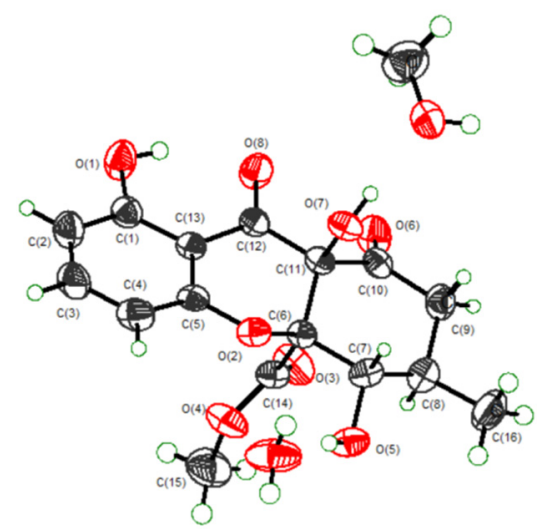

Figure 4. ORTEP diagram for the single-crystal X-ray of Amycochromone F (6).

Further analysis of the structures allowed us to raise a plausible biosynthetic pathway of compounds 1-6. As outlined in the Scheme 1, compounds 1-5 were structurally related to the known metabolite 6-methoxymethyleugenin, which was derived from the widely existing 5,7-dihydroxy-2-methylchromone via the hydroxymethylation with formaldehyde and the methylation with SAM (S-adenosyl methionine). The compound 1 was the dimerization of 6-methoxymethyleugenin, and the sequential methylation with SAM could afford the related compound 2. For compound 3-5, we proposed that the sulfur in these structures was from L-cysteine. Thus, the Michael addition of L-cysteine to the ortho-quinone methide intermediate from 6-methoxymethyleugenin gave the compound I. Then, transamination, decarboxylation and reduction sequence of I furnished the 2-sulfo-ethanol II occurred. An oxidation of sulfur in II gave the compound III. Finally, compound 3 was obtained through the double oxidation of sulfur in II. The oxidation of the hydroxyl group in III to the corresponding carboxylic acid occurred and followed with a decarboxylation afforded for compound 5. Furthermore, compound 4 was the oxidation product of 5 [24,25]. In addition, compound 6 was the oxidation product of the known natural product blennolide B, which was proposed by Franck to be a derivative of emodin (Scheme 2) [26]. 


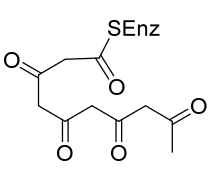

poly- $\beta$-keto chain<smiles>Cc1cc(=O)c2c(O)cc(O)cc2o1</smiles><smiles>COc1cc2oc(C)cc(=O)c2c(O)c1CO</smiles>

6-methoxymethyleugenin<smiles>[14CH3][14CH2][14CH2][14CH2]C=O</smiles><smiles>COc1cc2oc(C)cc(=O)c2c(O)c1CS(C)(=O)=O</smiles>

4

[O]<smiles>COc1cc2oc(C)cc(=O)c2c(O)c1CS(C)(=O)=O</smiles>
$-\mathrm{CO}_{2} \uparrow_{[\mathrm{O}]}^{\mathbf{5}}$<smiles>COc1cc2oc(C)cc(=O)c2c(O)c1CSC[C@H](N)C(=O)O</smiles>

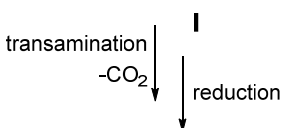

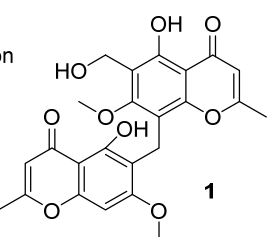<smiles>[AsH3]</smiles>

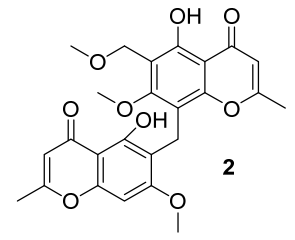<smiles>COc1cc2oc(C)cc(=O)c2c(O)c1CS(=O)(=O)CCO</smiles>

3<smiles>COc1cc2oc(C)cc(=O)c2c(O)c1CS(=O)(=O)CCO</smiles>

III<smiles>COc1cc2oc(C)cc(=O)c2c(O)c1CSCCO</smiles>

II

Scheme 1. Proposed hypothetical biosynthesis pathway of 1-5.

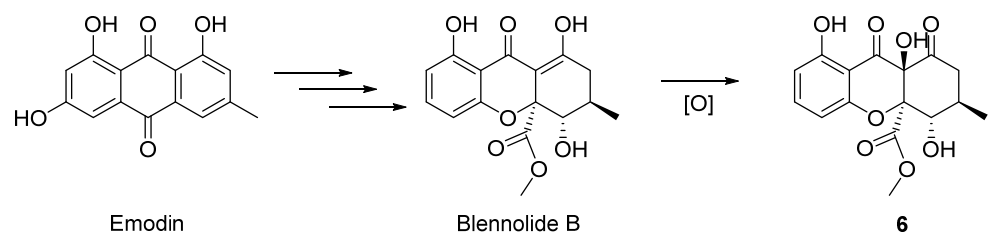

Scheme 2. Proposed hypothetical biosynthesis pathway of 6 .

The structures of five known compounds were identified as 6-ethoxymethyleugenin (7), 6-methoxymethyleugenin (8), 6-hydroxymethyleugenin (9), emodin (10) and the ascomycete metabolite chaetoquadrin D (11) by comparison of spectroscopic data with reported values and are described here for the first time as produced by Amycolatopsis sp.

The AlkB family of DNA repair enzymes utilize an $\alpha$-ketoglutarate/Fe(II)-dependent mechanism to oxidize the aberrant alkyl groups, finally repairing alkyl DNA bases $[27,28]$. Compounds 1-11 were evaluated for their in vitro ABH2 inhibitory activities. Compounds 1-11 exhibited weak inhibitory activity against the ABH2 enzyme. However, in 2019, a paper was published that tested emodin (10). It exhibited strong inhibitory activity for the ALKH3 enzyme with $\mathrm{IC}_{50}$ of $8.8 \mu \mathrm{M}$ [29]. This hinted that these compounds might inhibit other members of the AlkB family of enzymes.

In conclusion, the chemical investigation of a streptomycin-resistant strain of the deepsea marine actinomycete, Amycolatopsis sp. WP1, led to the isolation and identification of six novel compounds, amycolachromones A-F (1-6) and five known analogues (7-11). Among them, amycolachromones A-B (1-2) represents an unusual fused skeleton between two 6-hydroxymethyleugenin, and the relative configuration of amycolachromones $\mathrm{F}(6)$ was determined by the signal-crystal X-ray diffraction. The discovery of amycolachromones A-F not only expanded the chemical diversity of natural products and inspire further synthetic studies, but also provided a template for the exploration of inhibitors of other members of the AlkB family of enzymes.

\section{Materials and Methods}

General experimental procedures. All chemical reagents and solvents were purchased from Sigma-Aldrich (Shanghai, China). UV spectra were acquired with a DU $800 \mathrm{UV} / \mathrm{vis}$ spectrophotometer (Beckman Coulter, Brea, CA, USA). IR spectra were acquired with a 
Nicolet 380 FT-IR (Thermo Electron Corporation, Beverly, MA, USA). NMR experiments were conducted using an Agilent NMR $500 \mathrm{MHz}$ spectrometer (Santa Clara, CA, USA) and BRUKER NMR $600 \mathrm{MHz}$ spectrometer (San Jose, $\mathrm{CA}$, USA) with $\left(\mathrm{CD}_{3}\right)_{2} \mathrm{SO}$ as the solvent (referenced to residual DMSO at $\delta_{\mathrm{H}} 2.54$ and $\delta_{\mathrm{C}} 39.5$ ) at $25^{\circ} \mathrm{C}$. Electrospray ionization mass spectra (ESIMS) were acquired using an AB Sciex TripleTOF 4600 spectrometer (Boston, MA, USA) in the positive and negative ion mode. HPLC experiments were performed on a Hitachi Elite LaChrom system (Tokyo, Japan) equipped with a diode array detector model L-2450, pump L-2130 and autosampler L-2200. Semipreparative HPLC experiments were completed with a Waters XBridge Prep $C_{18}$ (Miflord, CO, USA) $5 \mu \mathrm{m}, 10 \mathrm{~mm} \times 250 \mathrm{~mm}$ column and Phenomenex Luna $\mathrm{C}_{18} 5 \mu \mathrm{m}, 250 \mathrm{~mm} \times 21.2 \mathrm{~mm}$ column.

Bacterial Strain and Culture Conditions. The WP1 strain (CGMCC No. 10738) was isolated from deep-sea sediments of the Southwest Indian Ocean and identified as Amycolatopsis sp. by $16 \mathrm{~S}$ rRNA sequence comparison. WP1 was grown in $\mathrm{ISP}_{2}$ medium consisting of $1.0 \%(w / v)$ malt extract, $0.4 \%(w / v)$ yeast extract, $0.4 \%(w / v)$ glucose and $3 \%(w / v)$ sea salt, the $\mathrm{pH}$ of medium was adjusted to 7.4 using $2 \mathrm{M} \mathrm{HCl}$ and $2 \mathrm{M} \mathrm{NaOH}$.

Mutants of strain WP1. The WP1 strain suspensions were spread onto $\mathrm{ISP}_{2}$ plates containing different concentrations $(0,10,20,30,40,50$ and $60 \mathrm{mg} / \mathrm{mL})$ of streptomycin. The plates were incubated at $37^{\circ} \mathrm{C}$ for 7 days. Mutant colonies producing the white pigment different than the WP1 strain were selected, generating mutant strain L-30-6, which was obtained on the $\mathrm{IPS}_{2}$ plate containing $30 \mathrm{mg} / \mathrm{mL}$ streptomycin.

Extraction and isolation. The mutant L-30-6 strain was inoculated into $\mathrm{ISP}_{2}$ broth with $3 \%$ sea salt in $250 \mathrm{~mL}$ Erlenmeyer flasks, at $30^{\circ} \mathrm{C}$ on a rotary shaker at $180 \mathrm{rpm}$ for 2 days as seed culture. Each of the seed cultures $(32 \mathrm{~mL})$ was transferred into $1 \mathrm{~L}$ Erlenmeyer flasks containing $400 \mathrm{~mL}$ of $\mathrm{ISP}_{2}$ supplemented with $3 \%$ sea salt. These flasks were incubated at $30{ }^{\circ} \mathrm{C}$ on a rotary shaker at $180 \mathrm{rpm}$ for 6 days. The resulting cultures $(60 \mathrm{~L})$ were centrifuged to yield the supernatant and a mycelial pellet. The supernatant was adsorbed onto macroporous resin XAD16N (DOW, St. Louis, Missouri, CA, USA) and eluted with linear gradient of $0-100 \% \mathrm{EtOH}$ in $\mathrm{H}_{2} \mathrm{O}$ to afford six fractions (A-F).

Fraction C ( $3.8 \mathrm{~g}$ ) was subjected to semipreparative HPLC (Phenomenex Luna $\mathrm{C}_{18}$, $250 \mathrm{~mm} \times 21.2 \mathrm{~mm}, 5 \mu \mathrm{m}, 10 \mathrm{~mL} / \mathrm{min}$ ) using a gradient solvent from $40-90 \% \mathrm{MeOH}$ in $\mathrm{H}_{2} \mathrm{O}$ over 30 min to give five fractions (C1-C5). Fraction $\mathrm{C} 2$ was further purified by semipreparative HPLC (Waters XBridge Prep $\mathrm{C}_{18} 5 \mu \mathrm{m}, 10 \mathrm{~mm} \times 250 \mathrm{~mm}, 4 \mathrm{~mL} / \mathrm{min}$ ) using an isocratic solvent system of $\mathrm{CH}_{3} \mathrm{CN}: \mathrm{H}_{2} \mathrm{O}$ (15:85) over 30 min to afford compound $6(10.2 \mathrm{mg})$ and C2A. Subfraction C2A was further purified by preparative HPLC with $\mathrm{MeOH}-\mathrm{H}_{2} \mathrm{O}$ (45:55) to provide compound 7 (2.6 mg). Fraction $\mathrm{C} 3$ was further purified by semipreparative HPLC with $\mathrm{MeOH}-\mathrm{H}_{2} \mathrm{O}$ (45:55) to yield compound 12 (6.5 mg), 3 $(3.1 \mathrm{mg})$ and $4(2.2 \mathrm{mg})$. Fraction $\mathrm{C} 4$ was further purified by semipreparative HPLC with $\mathrm{MeOH}: \mathrm{H}_{2} \mathrm{O}$ (45:55) to afford compound 5 (2.2 mg).

Fraction D (2.1 g) was subjected to semipreparative HPLC (Phenomenex Luna C18, $250 \mathrm{~mm} \times 21.2 \mathrm{~mm}, 5 \mu \mathrm{m}, 10 \mathrm{~mL} / \mathrm{min}$ ) using a gradient solvent from $50-80 \% \mathrm{MeOH}$ in $\mathrm{H}_{2} \mathrm{O}$ over 30 min to generate five fractions (D1-D5). Fraction D3 was further purified by semipreparative HPLC using an isocratic solvent system of $\mathrm{MeCN}: \mathrm{H}_{2} \mathrm{O}$ (50:50) to afford compound $1(1.7 \mathrm{mg})$ and compound $2(1.8 \mathrm{mg})$. D4 was subjected to preparative HPLC with $\mathrm{MeCN}: \mathrm{H}_{2} \mathrm{O}(30: 70)$ to provide compounds $\mathbf{9}(35.3 \mathrm{mg})$ and $\mathbf{1 0}(13.5 \mathrm{mg})$. D5 was further purified by preparative HPLC with $\mathrm{MeOH}-\mathrm{H}_{2} \mathrm{O}$ (45:55) to yield compounds 8 $(1.9 \mathrm{mg})$ and $11(6.8 \mathrm{mg})$. The following are details of the extraction and isolation of the compounds.

Amycolachromone A (1): White, amorphous powder; UV (MeOH) $\lambda \max (\log \varepsilon) 253$ (3.28) nm; IR (ZnSe) $v_{\max } 3426,3195,2844,1656,1445,1008 \mathrm{~cm}^{-1} ;{ }^{1} \mathrm{H}$ and ${ }^{13} \mathrm{C}$ NMR data, Table 1; HRESIMS $m / z$ 477.1172 [M + Na] ${ }^{+}$(calcd for $\mathrm{C}_{24} \mathrm{H}_{22} \mathrm{O}_{9}, 477.1162$ ).

Amycolachromone B (2): White, amorphous powder; UV (MeOH) $\lambda \max (\log \varepsilon) 254$ (3.46) nm; IR (ZnSe) $v_{\max } 3460,3190,2894,1658,1445,1008 \mathrm{~cm}^{-1} ;{ }^{1} \mathrm{H}$ and ${ }^{13} \mathrm{C}$ NMR data, Table 1; HRESIMS $m / z 469.1502[\mathrm{M}+\mathrm{H}]^{+}$(calcd for $\mathrm{C}_{25} \mathrm{H}_{24} \mathrm{O}_{9}, 469.1499$ ), $m / z 491.1333$ [M $+\mathrm{Na}^{+}($calcd 469.1318). 
Amycolachromone C (3): White, amorphous powder; UV (MeOH) $\lambda \max (\log \varepsilon) 250$ (3.43), 233 (3.46) nm; IR (ZnSe) $v_{\max } 3420,3199,2993,1650,1310,1089 \mathrm{~cm}^{-1} ;{ }^{1} \mathrm{H}$ and ${ }^{13} \mathrm{C}$ NMR data, Table 2; HRESIMS $m / z 351.0515$ [M + Na] ${ }^{+}$(calcd for $\mathrm{C}_{14} \mathrm{H}_{16} \mathrm{O}_{7} \mathrm{~S}, 351.0514$ ).

Amycolachromone D (4): White, amorphous powder; UV (MeOH) $\lambda \max (\log \varepsilon) 250$ (3.56), 233 (3.58) nm; IR (ZnSe) $v_{\max } 3520,32,469,2990,1750,1281,1008 \mathrm{~cm}^{-1} ;{ }^{1} \mathrm{H}$ and ${ }^{13} \mathrm{C}$ NMR data, Table 2; HRESIMS $m / z 321.0406$ [M + Na] ${ }^{+}$(calcd for $\mathrm{C}_{13} \mathrm{H}_{14} \mathrm{O}_{6} \mathrm{~S}, 321.0409$ ).

Amycolachromone E (5): White, amorphous powder; $\mathrm{UV}(\mathrm{MeOH}) \lambda \max (\log \varepsilon) 250$ (3.61), 240 (3.61) nm; IR (ZnSe) $v_{\max } 3470,3122,2880,1603,1210,1089 \mathrm{~cm}^{-1} ;{ }^{1} \mathrm{H}$ and ${ }^{13} \mathrm{C}$ NMR data, Table 2; HRESIMS $m / z 305.0462$ [M + Na] ${ }^{+}$(calcd for $\mathrm{C}_{13} \mathrm{H}_{14} \mathrm{O}_{5} \mathrm{~S}, 305.0460$ ).

Amycolachromone F (6): White, crystal; UV (MeOH) $\lambda \max (\log \varepsilon) 356$ (3.20), 277 (3.68) $\mathrm{nm}$; IR (ZnSe) $v_{\max } 3477,2956,2916,1748,1622,1475,1349,1083 \mathrm{~cm}^{-1} ;{ }^{1} \mathrm{H}$ and ${ }^{13} \mathrm{C}$ NMR data, Table 3; HRESIMS $m / z 337.0915[\mathrm{M}+\mathrm{H}]^{+}$(calcd for $\mathrm{C}_{16} \mathrm{H}_{16} \mathrm{O}_{8}, 337.0923$ ).

6-Ethoxymethyleugenin (7): White, amorphous powder; HR-ESIMS $m / z$ 287.0891 [M $+\mathrm{Na}]^{+}$(calcd for $\left.\mathrm{C}_{14} \mathrm{H}_{16} \mathrm{O}_{5}, 287.0985\right) .{ }^{1} \mathrm{H}-\mathrm{NMR}\left(600 \mathrm{MHz}, \mathrm{DMSO}-d_{6}\right): \delta_{\mathrm{H}} 13.19(\mathrm{~s}, \mathrm{OH}-5)$, $6.70(\mathrm{~s}, 1 \mathrm{H}, \mathrm{H}-8), 6.28(\mathrm{~s}, 1 \mathrm{H}, \mathrm{H}-3), 4.41\left(\mathrm{~s}, 2 \mathrm{H}, \mathrm{CH}_{2} \mathrm{OCH}_{3}\right), 3.89\left(\mathrm{~s}, 3 \mathrm{H}, \mathrm{OCH}_{3}\right), 3.44(\mathrm{q}, J=7.0$ $\left.\mathrm{Hz}, 2 \mathrm{H}, 6-\mathrm{CH}_{2} \mathrm{OCH}_{2}\right), 2.40\left(\mathrm{~s}, 3 \mathrm{H}, 2-\mathrm{CH}_{3}\right), 1.08\left(\mathrm{t}, J=7.0 \mathrm{~Hz}, 3 \mathrm{H}, \mathrm{OCH}_{2} \mathrm{CH}_{3}\right) .{ }^{13} \mathrm{C}-\mathrm{NMR}(150$ MHz, DMSO- $\left.d_{6}\right): \delta_{\mathrm{C}} 182.6(\mathrm{C}-4), 168.5$ (C-2), $164.3(\mathrm{C}-7), 159.9$ (C-5), 158.0 (C-8a), 109.1 (C-3), 108.9 (C-6), $104.4(\mathrm{C}-4 \mathrm{a}), 89.6(\mathrm{C}-8), 65.1\left(\mathrm{CH}_{2} \mathrm{OCH}_{3}\right), 59.3\left(6-\mathrm{CH}_{2} \mathrm{OCH}_{2}\right), 56.9\left(7-\mathrm{OCH}_{3}\right)$, $20.4\left(2-\mathrm{CH}_{3}\right)$ and $15.3\left(\mathrm{CH}_{2} \mathrm{CH}_{3}\right)$.

6-Methoxymethyleugenin (8): White, amorphous powder; HR-ESIMS $m / z 273.0738$ $[\mathrm{M}+\mathrm{Na}]^{+}$(calcd for $\left.\mathrm{C}_{13} \mathrm{H}_{14} \mathrm{O}, 273.0739\right) .{ }^{1} \mathrm{H}-\mathrm{NMR}\left(600 \mathrm{MHz}, \mathrm{CDCl}_{3}\right): \delta_{\mathrm{H}} 13.04(\mathrm{~s}, \mathrm{OH}-5)$, $6.36(\mathrm{~s}, 1 \mathrm{H}, \mathrm{H}-8), 6.04(\mathrm{~s}, 1 \mathrm{H}, \mathrm{H}-3), 4.55\left(\mathrm{~s}, 2 \mathrm{H}, \mathrm{CH}_{2} \mathrm{OCH}_{3}\right), 3.90\left(\mathrm{~s}, 3 \mathrm{H}, \mathrm{OCH}_{3}\right), 3.40(\mathrm{~s}, 3 \mathrm{H}$, $\left.\mathrm{CH}_{2} \mathrm{OCH}_{3}\right), 2.35\left(\mathrm{~s}, 3 \mathrm{H}, \mathrm{CH}_{3}\right) .{ }^{13} \mathrm{C}-\mathrm{NMR}\left(150 \mathrm{MHz}, \mathrm{CDCl}_{3}\right): \delta_{\mathrm{C}} 182.4(\mathrm{C}-4), 166.6(\mathrm{C}-2)$, 164.2 (C-7), 160.6 (C-5), 158.2 (C-8a), 109.1 (C-3), 108.9 (C-6), 105.1 (C-4a), 89.6 (C-8), 61.6 $\left(\mathrm{CH}_{2} \mathrm{OCH}_{3}\right), 58.2\left(\mathrm{CH}_{2} \mathrm{OCH}_{3}\right), 56.2\left(\mathrm{OCH}_{3}\right)$ and $20.4\left(2-\mathrm{CH}_{3}\right)$.

6-Hydroxymethyleugenin (9): White, amorphous powder; HRESIMS $m / z 259.0579$ [M $+\mathrm{Na}^{+}$(calcd for $\left.\mathrm{C}_{12} \mathrm{H}_{12} \mathrm{O}_{5}, 259.0582\right) .{ }^{1} \mathrm{H}-\mathrm{NMR}\left(600 \mathrm{MHz}, \mathrm{DMSO}-d_{6}\right): \delta_{\mathrm{H}} 13.09$ (s, OH-5), $6.65(\mathrm{~s}, 1 \mathrm{H}, \mathrm{H}-8), 6.24(\mathrm{~s}, 1 \mathrm{H}, \mathrm{H}-3), 4.55\left(\mathrm{t}, J=5.3 \mathrm{~Hz}, \mathrm{CH}_{2} \mathrm{OH}\right), 4.43(\mathrm{~d}, J=5.2 \mathrm{~Hz}, 2 \mathrm{H}, \mathrm{H}-9)$, $3.87\left(\mathrm{~s}, 3 \mathrm{H}, \mathrm{OCH}_{3}\right), 2.38\left(\mathrm{~s}, 3 \mathrm{H}, \mathrm{CH}_{3}\right) .{ }^{13} \mathrm{C}-\mathrm{NMR}\left(150 \mathrm{MHz}, \mathrm{DMSO}-d_{6}\right): \delta_{\mathrm{C}} 182.5(\mathrm{C}-4), 168.4$ (C-2), 164.1 (C-7), 159.1 (C-5), 157.7 (C-8a), 112.5 (C-6), 08.8 (C-3), 104.6 (C-4a), 90.7 (C-8), $56.7\left(\mathrm{OCH}_{3}\right), 50.9\left(\mathrm{CH}_{2} \mathrm{OH}\right)$ and $20.4\left(\mathrm{CH}_{3}\right)$.

Emodin (10): White, amorphous powder; HRESIMS $m / z 269.0448[\mathrm{M}-\mathrm{H}]^{-}$(calcd for $\left.\mathrm{C}_{15} \mathrm{H}_{12} \mathrm{O}_{5}, 269.0450\right) .{ }^{1} \mathrm{H}-\mathrm{NMR}\left(500 \mathrm{MHz}, \mathrm{DMSO}-d_{6}\right): \delta_{\mathrm{H}} 12.07(\mathrm{~d}, J=19.5 \mathrm{~Hz}, 2 \mathrm{H}, \mathrm{OH})$, $7.49(\mathrm{~d}, J=1.1 \mathrm{~Hz}, 1 \mathrm{H}, \mathrm{H}-5), 7.16(\mathrm{~s}, 1 \mathrm{H}, \mathrm{H}-7), 7.10(\mathrm{~d}, J=2.4 \mathrm{~Hz}, 1 \mathrm{H}, \mathrm{H}-4), 6.57(\mathrm{~d}, J=2.4$ $\mathrm{Hz}, 1 \mathrm{H}, \mathrm{H}-2), 2.41\left(\mathrm{~s}, 3 \mathrm{H}, \mathrm{CH}_{3}\right) .{ }^{13} \mathrm{C}-\mathrm{NMR}\left(150 \mathrm{MHz}, \mathrm{DMSO}-d_{6}\right): \delta_{\mathrm{C}} 190.0(\mathrm{C}-9), 182.0$ (C-10), 166.6 (C-6), 165.0 (C-8), 161.9 (C-1), 148.6 (C-3), 135.6 (C-10a), 133.3 (C-4a), 24.6 (C-2), 120.9 (C-4), 113.9 (C-9a), 109.6 (C-5), $109.2(\mathrm{C}-7), 108.4(\mathrm{C}-8 \mathrm{a})$ and $22.0\left(\mathrm{CH}_{3}\right)$.

Chaetoquadrin D (11): White, amorphous powder; HRESIMS $m / z$ HR-ESIMS $m / z$ $370.0969[\mathrm{M}+\mathrm{H}]^{+}$(calcd for $\left.\mathrm{C}_{16} \mathrm{H}_{19} \mathrm{NO}_{7} \mathrm{~S}, 370.0960\right) .{ }^{1} \mathrm{H}-\mathrm{NMR}\left(500 \mathrm{MHz}, \mathrm{DMSO}-d_{6}\right): \delta_{\mathrm{H}}$ $13.43(\mathrm{~s}, 5-\mathrm{OH}), 8.08(\mathrm{t}, \mathrm{NH}), 6.79(\mathrm{~s}, \mathrm{H}-8), 6.32(\mathrm{~s}, \mathrm{H}-3), 4.36\left(\mathrm{~s}, \mathrm{H}-1^{\prime}\right), 3.92\left(\mathrm{~s}, 7-\mathrm{OCH}_{3}\right), 3.45$ $\left(\mathrm{dd}, J=13.6,6.1 \mathrm{~Hz}, \mathrm{H}-4^{\prime}\right), 3.20\left(\mathrm{t}, J=7.0 \mathrm{~Hz}, \mathrm{H}-3^{\prime}\right), 2.41\left(\mathrm{~s}, 2-\mathrm{CH}_{3}\right), 1.81\left(\mathrm{~s}, \mathrm{H}-7^{\prime}\right) .{ }^{13} \mathrm{C}-\mathrm{NMR}$ (125 MHz, DMSO- $d_{6}$ ): $\delta_{\mathrm{C}} 182.4(\mathrm{C}-4), 70.1\left(\mathrm{C}-6^{\prime}\right), 169.0(\mathrm{C}-2), 163.7$ (C-7), 159.9 (C-5), 158.2 (C-8a), 108.9 (C-3), 104.5 (C-4a), 100.8 (C-6), $91.4(\mathrm{C}-8), 57.3\left(7-\mathrm{OCH}_{3}\right), 52.9\left(\mathrm{C}-3^{\prime}\right), 48.5\left(\mathrm{C}-1^{\prime}\right)$, $32.9\left(\mathrm{C}-4^{\prime}\right), 22.9\left(\mathrm{C}-7^{\prime}\right)$ and $20.42\left(2-\mathrm{CH}_{3}\right)$.

X-ray Crystallographic Analysis of Compound 6. Crystals of $\mathbf{6}$ were obtained in the mixed solvent comprising $\mathrm{MeOH}$ and $\mathrm{H}_{2} \mathrm{O}$, and crystallographic data were deposited at the Cambridge Crystallographic Data Centre (CCDC) under the reference number CCDC 1873441. The X-ray diffraction data were collected with Mo K $\alpha$ radiation $(\lambda=0.71073 \AA)$. The structure was solved by direct methods using the SHELXS-97 program. Orthorhombic $\mathrm{C}_{16} \mathrm{H}_{16} \mathrm{O}_{8}, \mathrm{CH}_{4} \mathrm{O}, \mathrm{H}_{2} \mathrm{O}, \mathrm{a}=7.7760(3) \AA, \mathrm{b}=8.6993(4) \AA, \mathrm{c}=26.8196(11) \AA, \alpha=90^{\circ}$, $\beta=90^{\circ}, \gamma=90^{\circ}, \mathrm{V}=1814.23(13) \AA 3 \mathrm{Z}, \mathrm{Z}=4, \rho \mathrm{Calcd}=1.414 \mathrm{~g} / \mathrm{cm}^{3}, \mu=0.118 \mathrm{~mm}^{-1}$, and $\mathrm{F}(0$ $00)=816$. Measurements were in the range $3.038^{\circ} \leq \theta \leq 26.368^{\circ}$, with 3697 independent reflections, of which 3133 unique reflections with I $>2 \sigma$ (I) were collected for the analysis, 
Rint $=0.0332$. The final $\mathrm{R}$ indices: $\mathrm{R} 1=0.0455, \mathrm{wR} 2=0.1177[\mathrm{I}>2 \sigma(\mathrm{I})], \mathrm{R}$ indices (all data): $\mathrm{R} 1=0.0566, \mathrm{wR} 2=0.1256$, and largest difference peak and hole: 0.560 and -0.231 e $\AA-3$.

The ABH2 family DNA repair enzyme assay. Effects of compounds $\mathbf{1 - 1 1}$ on the ABH2 family demethylase activity reactions on m3c-ss-DNA were evaluated. All reactions were performed at $37{ }^{\circ} \mathrm{C}$ in reaction buffer $\left[5 \mu \mathrm{M} \mathrm{Fe}\left(\mathrm{NH}_{4}\right)_{2}\left(\mathrm{SO}_{4}\right)_{2}, 0.93 \mathrm{mM} \alpha\right.$-ketoglutarate, $1.86 \mathrm{mM}$ ascorbic acid, and $46.56 \mathrm{mM}$ HEPES ( $\mathrm{pH}$ 8.0)] for $1 \mathrm{~h}$. Varying concentrations of compounds 1-11 $(0,5.0,7.5,20,30,40,50,75$ and $100 \mu \mathrm{M})$ were used for tests. The $\mathrm{m} 3 \mathrm{c}$-ss-DNA was pre-mixed with reaction buffer in a concentration of $5.0 \mu \mathrm{M}$. The reactions were initiated by adding $2.0 \mu \mathrm{M}$ ABH2. The reactions were stopped by adding $10.0 \mathrm{mM}$ EDTA followed by heating to $95^{\circ} \mathrm{C}$ for $5 \mathrm{~min}$. All the results of reaction were analyzed by HPLC. All reaction samples were quantified by DNApac PA-100 column (4 mm $\times 250 \mathrm{~mm}$, Thermo Scientific, (Waltham, MA, USA) with isocratic $60 \%$ mobile B, $1.5 \mathrm{M}$ ammonium acetate, under a constant flow rate of $1.0 \mathrm{~mL} / \mathrm{min}$. Mobile A was water. The UV detection wavelength was $260 \mathrm{~nm}$.

Supplementary Materials: The following supporting information can be downloaded at: https:/ www. mdpi.com/article/10.3390/md20030162/s1. Figures S1-S35: 1D and 2D NMR, HRESI mass spectra, and crystal data for compounds 1-6. Table S1. Crystallographic data for Amycochromone F (6).

Author Contributions: J.C. (Jianwei Chen), J.C. (Jun Chen), S.W., X.B., S.L., B.W., H.Z. and H.W. performed the experiments and analyzed the data; S.L. and B.W. contributed materials and analysis tools; J.C. (Jianwei Chen) and H.W. wrote the paper. All authors have read and agreed to the published version of the manuscript.

Funding: This research was funded by Key Research and Development Program of Zhejiang Province (2021C03084), Natural Foundation of Zhejiang Province (LGF21H300003), National Key R\&D Program of China (2018YFC0311003, 2017YFE0103100), High-level Talent Special Support Plan of Zhejiang Province (2019R52009).

Institutional Review Board Statement: No applicable.

Informed Consent Statement: No applicable.

Acknowledgments: We thank Hang Ma, Hilary Ranson, Navindra P. Seeram, Deyu Li, David C. Rowley and $\mathrm{Al}$ Bach at the College of Pharmacy, University of Rhode Island for their kind assistance.

Conflicts of Interest: The authors declare no competing financial interest.

\section{References}

1. Blunt, J.W.; Copp, B.R.; Keyzers, R.A.; Munro, M.H.G.; Prinsep, M.R. Marine Natural Products. Nat. Prod. Rep. 2017, 34, 235-294. [CrossRef] [PubMed]

2. $\quad$ Blunt, J.W.; Copp, B.R.; Keyzers, R.A.; Munro, M.H.; Prinsep, M.R. Marine Natural Products. Nat. Prod. Rep. 2016, 33 , $382-431$. [CrossRef] [PubMed]

3. Blunt, J.W.; Copp, B.R.; Keyzers, R.A.; Munro, M.H.; Prinsep, M.R. Marine Natural Products. Nat. Prod. Rep. 2015, 32, 116-211. [CrossRef]

4. Nutzmann, H.W.; Reyes-Dominguez, Y.; Scherlach, K.; Schroeckh, V.; Horn, F.; Gacek, A.; Schumann, J.; Hertweck, C.; Strauss, J.; Brakhage, A.A. Bacteria-induced Natural Product Formation in the Fungus Aspergillus nidulans Requires Saga/Ada-mediated Histone Acetylation. Proc. Natl. Acad. Sci. USA 2011, 108, 14282-14287. [CrossRef]

5. Bentley, S.D.; Chater, K.F.; Cerdeno-Tarraga, A.M.; Challis, G.L.; Thomson, N.R.; James, K.D.; Harris, D.E.; Quail, M.A.; Kieser, H.; Harper, D.; et al. Complete Genome Sequence of the Model Actinomycete Streptomyces coelicolor A3(2). Nature 2002, 417, 141-147. [CrossRef]

6. Nett, M.; Ikeda, H.; Moore, B.S. Genomic Basis for Natural Product Biosynthetic Diversity in the Actinomycetes. Nat. Prod. Rep. 2009, 26, 1362-1384. [CrossRef]

7. Bode, H.B.; Bethe, B.; Hofs, R.; Zeeck, A. Big Effects from Small Changes: Possible Ways to Explore Nature's Chemical Diversity. Chembiochem 2002, 3, 619-627. [CrossRef]

8. Chen, J.; Zhang, H.; Ye, X.; Wei, B.; Emam, M.; Zhang, H.; Wang, H. The Structural Diversity of Marine Microbial Secondary Metabolites Based on Co-Culture Strategy: 2009-2019. Mar. Drugs 2020, 18, 449. [CrossRef]

9. Henrikson, J.C.; Hoover, A.R.; Joyner, P.M.; Cichewicz, R.H. A Chemical Epigenetics Approach for Engineering the in Situ Biosynthesis of a Cryptic Natural Product from Aspergillus niger. Org. Biomol. Chem. 2009, 7, 435-438. [CrossRef] 
10. Ochi, K.; Hosaka, T. New strategies for drug discovery: Activation of silent or weakly expressed microbial gene clusters. Appl. Microbiol. Biotechnol. 2013, 97, 87-98. [CrossRef]

11. Ochi, K.; Tanaka, Y.; Tojo, S. Activating the Expression of Bacterial Cryptic Genes by rpoB Mutations in RNA Polymerase or by Rare Earth Elements. J. Ind. Microbiol. Biotechnol. 2014, 41, 403-414. [CrossRef]

12. Shima, J.; Hesketh, A.; Okamoto, S.; Kawamoto, S.; Ochi, K. Induction of Actinorhodin Production by rpsL (Encoding Ribosomal Protein S12) Mutations that Confer Streptomycin Resistance in Streptomyces lividans and Streptomyces coelicolor A3(2). J. Bacteriol. 1996, 178, 7276-7284. [CrossRef]

13. Fdhila, F.; Vazquez, V.; Sanchez, J.L.; Riguera, R. DD-diketopiperazines: Antibiotics Active against Vibrio anguillarum Isolated from Marine Bacteria Associated with Cultures of Pecten maximus. J. Nat. Prod. 2003, 66, 1299-1301. [CrossRef]

14. Zhang, Y.; Huang, H.; Xu, S.; Wang, B.; Ju, J.; Tan, H.; Li, W. Activation and Enhancement of Fredericamycin A production in Deepsea-derived Streptomyces somaliensis SCSIO ZH66 by Using Ribosome Engineering and Response Surface Methodology. Microb. Cell Fact. 2015, 14, 64. [CrossRef]

15. Fu, P.; Jamison, M.; La, S.; MacMillan, J.B. Inducamides A-C, Chlorinated Alkaloids from an RNA Polymerase Mutant Strain of Streptomyces sp. Org. Lett. 2014, 16, 5656-5659. [CrossRef]

16. Gaspar, A.; Matos, M.J.; Garrido, J.; Uriarte, E.; Borges, F. Chromone: A Valid Scaffold in Medicinal Chemistry. Chem. Rev. 2014, 114, 4960-4992. [CrossRef]

17. Reis, J.; Gaspar, A.; Milhazes, N.; Borges, F. Chromone as a Privileged Scaffold in Drug Discovery: Recent Advances. J. Med. Chem. 2017, 60, 7941-7957. [CrossRef]

18. Sumarah, M.W.; Puniani, E.; Blackwell, B.A.; Miller, J.D. Characterization of Polyketide Metabolites from Foliar Endophytes of Picea glauca. J. Nat. Prod. 2008, 71, 1393-1398. [CrossRef]

19. Zhang, F.; Li, L.; Niu, S.; Si, Y.; Guo, L.; Jiang, X.; Che, Y. A Thiopyranchromenone and Other Chromone Cerivatives from an Endolichenic fungus, Preussia africana. J. Nat. Prod. 2012, 75, 230-237. [CrossRef]

20. Tuntiwachwuttikul, P.; Phansa, P.; Pootaeng-On, Y.; Taylor, W.C. Chromones from the Branches of Harrisonia perforata. Chem. Pharm. Bull. 2006, 54, 44-47. [CrossRef]

21. Feng, Y.J.; Blunt, J.W.; Cole, A.L.J.; Munro, M.H.G. The Isolation of Two New Chromone Derivatives from the New Zealand fungus Tolypocladium extinguens. J. Nat. Prod. 2002, 65, 1681-1682. [CrossRef] [PubMed]

22. Yong, K.; Kaleem, S.; Yi, W.W.; Wu, B.; Zhang, Z.Z. New Polyhydroxanthones from the Marine-Associated Fungus Penicillium sp. ZZ1750. Tetrahedron Lett. 2021, 81, 153354. [CrossRef]

23. El-Elimat, T.; Raja, H.A.; Day, C.S.; McFeeters, H.; McFeeters, R.L.; Oberlies, N.H. $\alpha$-Pyrone derivatives, Tetra/Hexahydroxanthones, and Cyclodpsipeptides from Two Freshwater Fungi. Bioorg. Med. Chem. 2017, 25, 795-804. [CrossRef] [PubMed]

24. Qin, T.; Porco, J.A., Jr. Total Syntheses of Secalonic Acids A and D. Angew. Chem. Int. Ed. Engl. 2014, 53, 3107-3110. [CrossRef]

25. Qin, T.; Iwata, T.; Ransom, T.T.; Beutler, J.A.; Porco, J.A., Jr. Syntheses of Dimeric Tetrahydroxanthones with Varied Linkages: Investigation of "Shapeshifting" Properties. J. Am. Chem. Soc. 2015, 137, 15225-15233. [CrossRef]

26. Franck, B.; Stöckigt, J.; Zeidler, U.; Franckowiak, G. Stereospezifische Synthese der 10-Methyl-10-desmethoxycarbonylhemisecalonsäure A. Chem. Ber. 1973, 106, 1198-1220. [CrossRef]

27. Chen, F.; Tang, Q.; Bian, K.; Humulock, Z.T.; Yang, X.; Jost, M.; Drennan, C.L.; Essigmann, J.M.; Li, D. Adaptive Response Enzyme AlkB Preferentially Repairs 1-Methylguanine and 3-Methylthymine Adducts in Double-Stranded DNA. Chem. Res. Toxicol. 2016, 29, 687-693. [CrossRef]

28. Bian, K.; Chen, F.; Humulock, Z.T.; Tang, Q.; Li, D. Copper Inhibits the alkb Family DNA Repair Enzymes under Wilson's Disease Condition. Chem. Res. Toxicol. 2017, 30, 1794-1796. [CrossRef]

29. Pilzys, T.; Marcinkowski, M.; Kukwa, W.; Garbicz, D.; Dylewska, M.; Ferenc, K.; Mieczkowski, A.; Kukwa, A.; Migacz, E.; Wolosz, D. ALKBH Overexpression in Head and Neck Cancer: Potential Target for Novel Anticancer Therapy. Sci. Rep. 2019, 9, 13249. [CrossRef] 